\title{
Boric Acid Radiolysis in Primary Coolant Water of PWR at Temperature of $250^{\circ} \mathrm{C}$
}

\author{
Geni Rina Sunaryo* \\ Center for Nuclear Reactor Technology and Safety, BATAN, Building 80 Puspiptek Area, Serpong, Tangerang Selatan, \\ Indonesia, 15310
}

\begin{tabular}{l}
\hline ARTICLE INFORMATION \\
\hline Article History: \\
Received: \\
13 January 2017 \\
Received in revised form: \\
21 February 2017 \\
Accepted: \\
23 February 2017 \\
\end{tabular}

Keyword:

Radiolysis

Boric acid

Gamma-ray

Facsimile

Oxygen concentration

\section{ABSTRACT}

BORIC ACID RADIOLYSIS IN PRIMARY COOLANT WATER OF PWR AT TEMPERATURE OF $250^{\circ} \mathrm{C}$. The existence of oxygen in the primary coolant system of PWR could lead to corrosion, hence it is very important to suppress the oxygen concentration in the system. Therefore, study of the effect of boric acid addition into the primary coolant water system of PWR to suppress oxygen concentration resulted from gamma-ray radiation is essential to be performed. The aim of this research is to understand reaction mechanism at temperature of $250^{\circ} \mathrm{C}$ and the effect of boric acid adding toward oxygen concentration in the PWR primary coolant water. Methodology used is simulation using Facsimile software. Input for the software namely radiolysis reaction mechanism for pure water, $\mathrm{G}$ value from radiolysis product, dose rate of 1 and $10^{4} \mathrm{~Gy} / \mathrm{s}$, aeration and deaeration system, and specific reaction of boric acid with hydroxyl radical and hydrated electron at temperature $25^{\circ} \mathrm{C}$ and $300^{\circ} \mathrm{C}$. The output are in the form of irradiation time vs oxygen concentration time series. The results show that the oxygen production increase significantly with the irradiation time and reach the saturated concentration at $10^{7} \mathrm{~s}$. Based on the plot of oxygen's concentration at $10^{7} \mathrm{~s}$ vs boric acid, several results are as following: oxygen concentration significantly suppressed by boric acid addition and gives the exponential decreasement, the higher dose rate gives the higher concentration of oxygen, the aeration system gives no effect on suppressing oxygen concentration at boric acid addition up to $0.1 \mathrm{M}$.

\begin{abstract}
ABSTRAK
RADIOLISIS ASAM BORAT DI AIR PENDINGIN PRIMER PWR PADA TEMPERATUR $250^{\circ} \mathrm{C}$ Adanya oksigen di dalam sistem pendingin primer PWR dapat menyebabkan korosi sehingga sangat penting untuk menekan konsentrasi oksigen dalam sistem tersebut. Oleh karena itu, studi pengaruh penambahan asam borat ke dalam air pendingin primer dari PWR untuk menekan konsentrasi oksigen yang dihasilkan akibat radiasi sinar-gamma penting untuk dilakukan. Tujuan penelitian adalah untuk memahami mekanisme reaksi hingga temperatur $250^{\circ} \mathrm{C}$ dan pengaruh penambahan asam borat terhadap konsentrasi oksigen di dalam sistem pendingin primer PWR. Metodologi yang digunakan adalah simulasi menggunakan perangkat lunak Facsimile. Input yang digunakan adalah mekanisme reaksi radiolisis untuk air murni, nilai$\mathrm{G}$ dari produk radiolisis, laju dosis 1 dan $10^{4} \mathrm{~Gy} / \mathrm{s}$, sistem aerasi dan deaerasi, dan reaksi spesifik dari asam borat dengan radikal hidroksil dan electron terhidrasi, pada temperatur $25^{\circ} \mathrm{C}$ dan $300^{\circ} \mathrm{C}$. Keluarannya berupa data runtun waktu iradiasi vs konsentrasi oksigen. Hasil simulasi menunjukkan bahwa produksi oksigen naik secara signifikan dengan lamanya waktu iradiasi dan mencapai kondisi tunak pada $t=10^{7} \mathrm{~s}$. Berbasis hasil plot antara konsentrasi oksigen pada $t=10^{7} s$ vs konsentrasi asam borat, memberikan hasil sebagai berikut: konsentrasi oksigen ditekan secara signifikan oleh adanya asam borat dan memberikan penurunan secara eksponensial, pengaruh laju dosis menunjukkan bahwa semakin tinggi laju dosis maka oksigen yang dihasilkan akan semakin banyak, dan pada kondisi aerasi, penambahan asam borat hingga $0,1 \mathrm{M}$ tidak memberikan efek yang berarti terhadap penekanan konsentrasi oksigen.

Kata kunci: radiolisis, asam borat, sinar gamma, facsimile, konsentrasi oksigen
\end{abstract}

\section{INTRODUCTION}

Boron, as boric acid, is being added in the primary water coolant system of Pressurized Water Reactor (PWR) as a fine neutron

*Penulis korespondensi

E-mail: genirina@batan.go.id moderator [1-4]. In addition to that, boric acid has been used for moderating the coolant water in interim spent fuel storage at accident affected Fukushima units. The effect of boric acid on oxidator and reductor species, that have been generated by irradiation have not 
known yet, especially at high temperature up to $250^{\circ} \mathrm{C}$. This is very important to understand the chemically condition, especially for the purpose on suppressing the corrosion process. The oxidator species are oxygen and hydrogen peroxide, and the reductor species are hydrogen gas.

The effect of boric acid addition in order to suppress the concentration of oxygen at room temperature by using Facsimile computer code has been done before[5]. The higher concentration of boric acid has been added up then the suppressed oxygen concentration will be much more. The linear relation between boric acid concentration and the degradation of oxygen in logarithm curve is well understood. However, the behavior at higher temperature of $250^{\circ} \mathrm{C}$ is not known yet.

The objective of this paper is to understand the effect of boric acid addition toward the oxygen under $\gamma$-rays irradiation up to temperature of $250^{\circ} \mathrm{C}$. The methodology applied is simulation by using 'Facsimile' software [6-8]. Inputs are reactions mechanism of pure water radiolysis, G-values of radiolysis products, dose rate of 1 and $10^{4}$ $\mathrm{Gy} / \mathrm{s}$, aeration and deaeration system, and specific reactions of boric acid with hydroxyl radical and hydrated electron, that are set for 25 and $250^{\circ} \mathrm{C}$. Outputs are series of irradiation time vs concentration of oxygen.

\section{METHODOLOGY}

The simulation method has been reported elsewhere [5,9-14]. Radiolysis simulation is an analysis of simultaneous chemical reactions and the integration of time-dependent multivariable simultaneous differential equations. A computer code 'FACSIMILE' was used to integrate differential equations. As inputs the $\mathrm{G}$-values, reaction set and rate constants are needed.

\subsection{G-values}

One of the important inputs at this simulation by using Facsimile software is $\mathrm{G}^{-}$ values, that is defined as a number of radicals or molecules produced per $100 \mathrm{Ev}$ energy absorbed. Set of radiolysis product as $\mathrm{G}^{-}$ values employed in this simulation is shown in Table 1.

\subsection{Reactions Set}

Set of reactions employed at this work, is based on Elliot's compilation [15] for pure water and listed in Table 2. In the simulation at room temperature, the reaction set is exactly the same as previous work $[5,14]$. Since the system is boric acid, therefore the reaction set of boric with probable radiolysis products is required. Two reactions of boric acid toward $\mathrm{OH}$ and $\mathrm{e}_{\mathrm{aq}}{ }^{-}$, were added to Elliot's reaction set (Table 2) [16]. Those rate constants at $25^{\circ} \mathrm{C}$ are well clarified but not for the higher temperature. Therefore, the rate constant of those reactions at $300^{\circ} \mathrm{C}$ was estimated by Arrhenius-type extrapolation using the activation energy of $70 \mathrm{~kJ} / \mathrm{mol}$.

Table 1. G-Values of Radiolysis Products Induced By $\gamma^{-}$ Rays Irradiation at 25 and $250^{\circ} \mathrm{C}$. [9-16]

\begin{tabular}{lcc}
\hline & \multicolumn{2}{c}{$\boldsymbol{\gamma}$-rays } \\
\cline { 2 - 3 } & $25^{\circ} \mathrm{C}$ & $250^{\circ} \mathrm{C}$ \\
\hline $\mathrm{e}_{\mathrm{aq}}{ }^{-}$ & 2.75 & 3.43 \\
$\mathrm{H}$ & 0.6 & 1.56 \\
$\mathrm{H}^{+}$ & 2.75 & 3.43 \\
$\mathrm{OH}$ & 2.81 & 5.74 \\
$\mathrm{H}_{2}$ & 0.44 & 0.64 \\
$\mathrm{H}_{2} \mathrm{O}_{2}$ & 0.71 & 0.265 \\
$-\mathrm{H}_{2} \mathrm{O}$ & 4.23 & 6.27 \\
\hline
\end{tabular}

\subsection{Dose Rate}

A very high dose rate of radiation which is coming from $\gamma$-rays, fast neutrons and $a^{-}$ rays, is exposed by the core in PWR. Different type of PWR may initiate a different dose rates in the core, and dose rate distribution is really depend on the distance from the core. In this simulation, dose rate used is reported elsewhere, as 1 and $10^{4} \mathrm{~Gy} \mathrm{~s}^{-1}$, and only for $\gamma^{-}$ rays irradiation[1].

\subsection{Water Chemistry Condition}

Boric acid concentration was induced in the simulation up to $1 \mathrm{M}$. Literally the concentration range applied in the field is around $0.3 \mathrm{M}$, but in this study the input data applied up to $1 \mathrm{M}$. The objective is to understand the concentration effect based on 
direct interaction between $\gamma$-rays irradiation and water. Therefore, no direct irradiation effect to the boric acid is considered. The initial concentration of oxygen which represents the aeration system is applied with the concentration of $2.5 \times 10^{-4} \mathrm{M}$ at $25^{\circ} \mathrm{C}[14]$.

\section{RESULTS AND DISCUSSION}

The simulation of radiolysis at $250^{\circ} \mathrm{C}$ was carried out. The validation of the sub routine was done and has been reported separately.[1,15] The results gave a good compromising with the previous work. Based on this, the further simulation of the effect at $250^{\circ} \mathrm{C}$ was done. The time variation of oxygen concentration is shown in Figure 1. It shows the effect of boric acid addition on oxygen production under $\gamma$-rays irradiation at $250^{\circ} \mathrm{C}$ in deaeration and aeration system, dose rate of $10^{4} \mathrm{~Gy} / \mathrm{s}$, and in the comparison with the at $25^{\circ} \mathrm{C}$.

The profile at $25^{\circ} \mathrm{C}$ in deaeration system is shown in Figure 1.a. In Figure 1.b, it is clear that the oxygen is produced in deaerated pure water which is irradiated by using $\gamma$-rays at $250^{\circ} \mathrm{C}$. The concentration depends on the irradiation time, get the optimum concentration in a certain irradiation time, and then become in a steady state condition. Compare with that in pure water profile, it shows that the existence of boric acid suppresses the oxygen concentration at its steady state condition. At the higher concentration of boric acid, the lower oxygen concentration is produced at its steady state condition. The effect of boric acid starts at different irradiation time, and seems faster at the higher concentration of boric acid.

Compare with that at Fig. 1.a., it is known that at higher temperature give the lower concentration of oxygen at its steady state condition. The effect of boric acid for both temperature clearly shows to suppress the oxygen suppressing, but it seems to be more effective at $250^{\circ} \mathrm{C}$.

In the comparison of Fig.1.a. and c., for pure water under dose rate of $10^{4} \mathrm{~Gy} / \mathrm{s}$, it is clear that both systems give the same concentration of oxygen at its steady state condition. It can be understood that the presence of oxygen in aeration system does not give any significant effect on the oxygen production. However, the effect of boric acid addition seems to be less productive in aeration system.
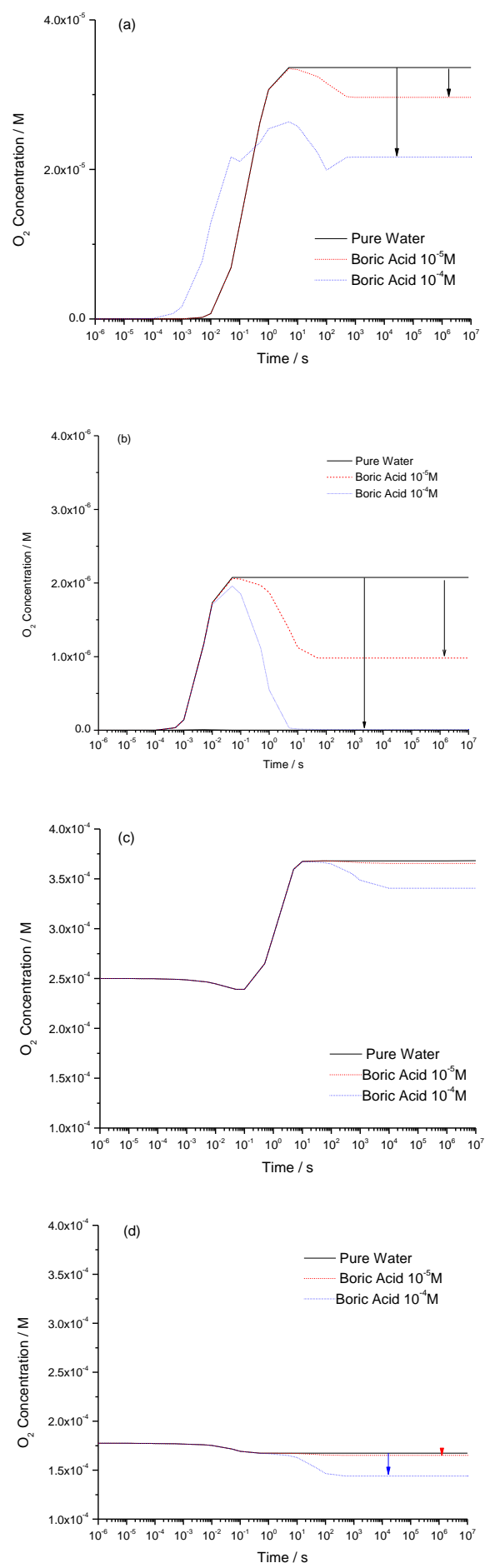

Figure 1. Time Variations of Oxygen Products in Various Water Chemistry Systems Under $\gamma$-Rays Irradiation $\left(10^{4} \mathrm{~Gy} / \mathrm{S}\right) \mathrm{At}(\mathrm{A}) 25^{\circ} \mathrm{C}$, Deaeration System,

(B) $250^{\circ} \mathrm{C}$, Deaeration System, (C) $25^{\circ} \mathrm{C}$, Aeration System and (d) $250^{\circ} \mathrm{C}$, Aeration System. 
By comparing Fig. 1c and d, it can be concluded that the initial oxygen concentration at $250^{\circ} \mathrm{C}$ is lower than at $25^{\circ} \mathrm{C}$ due to the density effect which is becoming approx. 0.8 at $250^{\circ} \mathrm{C}$. Therefore, the steady state concentration of oxygen is becoming lower than that at $25^{\circ} \mathrm{C}$. The effect of the boric acid existence, give a similar effect with that at $25^{\circ} \mathrm{C}$.

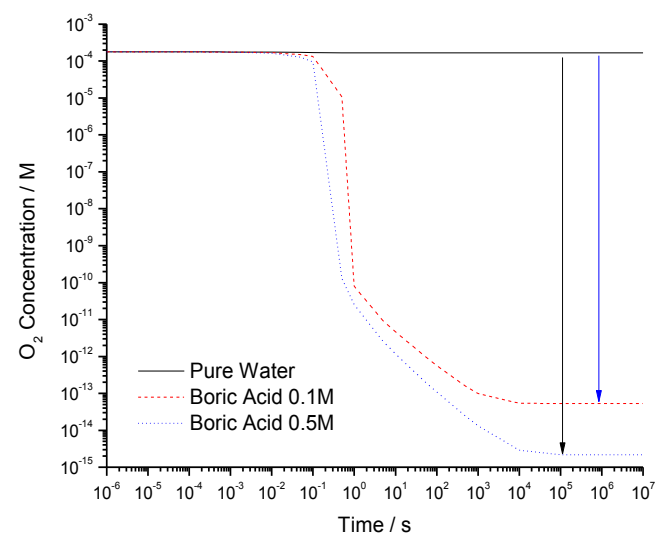

Figure 2. Time Variations of Oxygen Products in Aeration System with The Higher Boric Acid Addition, Under $\gamma^{-}$ Rays Irradiation $\left(10^{4} \mathrm{~Gy} / \mathrm{S}\right)$ at $250^{\circ} \mathrm{C}$.

In the Figure 2, it shows that in the addition of boric acid, $0.1 \mathrm{M}$, the oxygen production in aerated system is suppressed drastically, becoming in the range of $10^{-14} \mathrm{M}$, compare with that at Fig.1.d. that still in the range concentration of $10^{-4} \mathrm{M}$, at its steady state condition.

The steady state concentration of oxygen at various conditions, in pure water, under $\gamma$-rays irradiation at $250^{\circ} \mathrm{C}$ is listed at Table 3.

Table 3. The Steady State Concentration of Oxygen at Various Conditions, in Pure Water, Under $\gamma$-Rays

\begin{tabular}{ccc}
\hline $\begin{array}{c}\text { Dose rate } \\
(\mathrm{Gy} / \mathrm{s})\end{array}$ & System & $\begin{array}{r}\text { Steady state oxygen } \\
\text { concentration/M }\end{array}$ \\
\hline $10^{4}$ & Aeration & $3.68 \times 10^{-4}$ \\
& Deaeration & $3.36 \times 10^{-5}$ \\
1 & Aeration & $2.07 \times 10^{-4}$ \\
& Deaeration & $1.26 \times 10^{-7}$ \\
\hline
\end{tabular}

It is clear that at $250^{\circ} \mathrm{C}$, the dose rate effect is insignificant for aeration system, but 2 magnitudes different for deaeration system.

The boric acid concentration variations of oxygen products at its steady state concentration (at $10^{7} \mathrm{~s}$ ), in aeration system, under $\gamma$-rays irradiation $\left(10^{4} \mathrm{~Gy} / \mathrm{s}\right)$, at $250^{\circ} \mathrm{C}$, is shown in Figure 3.

The boric acid at low concentration of under $0.2 \mathrm{M}$, is very effective to suppress oxygen production, and become less significant for further concentration. While for boric acid concentration bigger than $0.2 \mathrm{M}$, the effect in aeration and deaeration system is negligible. The dose rate difference gives eligible effect clearly, which is at lower dose rate give the lower oxygen concentration. It means that the boric acid concentration is excess, therefore the scavenging capacity is very high toward oxygen at both deaeration and aeration system.

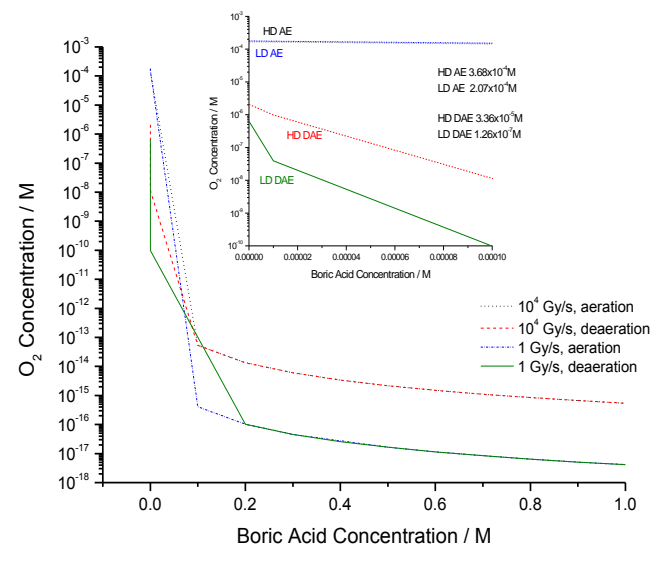

LD $: 1 \mathrm{~Gy} / \mathrm{s} \quad$ HD $: 10^{4} \mathrm{~Gy} / \mathrm{s}$

Figure 3. Boric Acid Concentration Variations of Oxygen Products at Its Steady State Concentration (at $10^{7} \mathrm{~s}$ ), in Aeration System, Under $\gamma$-Rays Irradiation $\left(10^{4} \mathrm{~Gy} / \mathrm{s}\right)$, at $250^{\circ} \mathrm{C}$.

\section{CONCLUSION}

Boric acid can suppress the presence of oxygen on primary water of PWR. The phenomenon is exponential decreasement. The presence of oxygen nearly depleted at boric acid addition up to $0.2 \mathrm{M}$. Further than that, the decreasement becomes less. It is understood that boric acid reacts mainly with hydroxyl radical than that with hydrated electron.

\section{ACKNOWLEDGEMENT}

Thank you for DIPA PTKRN BATAN that has given budgeting support for this experiment. 


\section{REFERENCES}

[1]. Febrianto, "The Effect of Boric Acid on Corrosion of SS304 as PWR Pressurizer Material," in International Conference on Nuclear Energy Technologies and Sciences (ICoNETS) Conference Proceedings, 2015.

[2]. N. S. Mahmoud, M. M. El-Fawal and A. A. Gadalla, "Assessment of Cooling Water Chemistry on the Safety of Cooling Power Reactors," 14th International Water Technology Conference (IWTC), Cairo, Egypt, 2010, pp. 877-890.

[3]. K. Ishigure, K. Abe, N. Nakajima, H. Nagao and S. Uchida, "Water Chemistry Experience of Nuclear Power Plants in Japan," Journal of Nuclear Science and Technology, Vol. 26, Issue 1, 1989.

[4]. S. Uchida and Y. Katsumura, "Water chemistry technology - one of the key technologies for safe and reliable nuclear power plant operation", Journal of Nuclear Science and Technology, Vol. 50, No. 4, 346-362, 2013.

[5]. G. R. Sunaryo, "Mekanisme Reaksi Asam Borat dengan Produk Radiolisis akibat Radiasi sinar- $\gamma$ pada Temperatur $25^{\circ} \mathrm{C}$, Jurnal Pengembangan Energi Nuklir, Vol. 14, No. 2, 2012.

[6]. FACSIMILE/CHEKMAT User's Manual, AERE Report R12805, Harwell Laboratory, Oxfordshire, England, 1987.

[7]. FACSIMILE v 4.0 User Guide, AEA Technology, Carlsbad, California, 1995.

[8]. FACSIMILE $v$ 4.0 Technical Reference, AEA Technology, Carlsbad, California, 2011.

[9]. G. R. Sunaryo, M. Jintana and J.P.J. Gerin "MonteCarlo Simulation of $\mathrm{\gamma}$-ray and Fast Neutron Radiolysis of Liquid Water and $0.4 \mathrm{M} \mathrm{H}_{2} \mathrm{SO}_{4}$ Solutions at Temperatures up to $325^{\circ} \mathrm{C}$, Jurnal Atom Indonesia, Vol. 37 No.1, p 29-35, 2011.

[10]. S. L. Butarbutar, S. Sanguanmith, J. Meesungnoes, G. R. Sunaryo and J.P Jay-Gerin, "Calculation of the Yields for the Primary Species formed from the Radiolysis of Liquid Water by Fast Neutrons at Temperatures between $25-350^{\circ} \mathrm{C} ", \quad$ Radiation Research, 181, pp. 659-665, 2014.

[11]. S.L. Butarbutar, G.R. Sunaryo, J. Meesungnoen and J.P. Jay-Gerin, "Temperature Dependence of the Primary Species Yields of Liquid Water Radiolysis by $0.8-\mathrm{MeV}$ Fast Neutrons", Jurnal Atom Indonesia, Vol 42, No 1, pp. 13 - 18, 2016.

[12]. G. R. Sunaryo, "Mekanisme Reaksi Asam Borat dengan Produk Radiolisis akibat Radiasi Sinargamma pada Temperatur 25C", Jurnal Pengembangan Energi Nuklir, Vol 14, No 2, pp. 74-84, 2012.

[13]. G. R. Sunaryo, "Karakteristik Produk Interaksi Radiasi Sinar-gamma dan Neutron dengan Air Pendingin PWR hingga Temperatur 300C", Presentasi Ilmiah Jabatan Peneliti Utama, Pusat Teknologi Reaktor dan Keselamatan Nuklir, Serpong, 2011.

[14]. G. R. Sunaryo and M. Domae, "Numerical Simulation on Effect of Methanol Addition on Coolant Radiolysis in Pressurized Water Reactor", Journal of Nuclear Science and Technology, Vol. 45, No. 12, pp 1261-1274, 2008.

[15]. A.J. Elliot, "Analyses The Reaction Set, Rate Constants and g-Values for the Simulation of the Radiolysis of Light Water over the Range $20^{\circ} \mathrm{C}$ to $350^{\circ} \mathrm{C}$ Based on Information Available in 2008", AECL EACL, 153-127160-450-001, Ontario, Canada, 2009.

[16]. G.V. Buxton and R.M. Sellers, 'Reactivity of Hydrated Electron and Hydroxyl Radical with Boric Acid in Aqueous Solutions', Journal of Radiation Applications and instrumentation. Part C. Radiation Physics and Chemistry, Vol 29, no 2, pp 137-140, 1987. 
Table 2. Reaction set in pure water system is based on Elliot's compilation. [15]

\begin{tabular}{|c|c|c|c|}
\hline \multirow{2}{*}{ No } & \multirow{2}{*}{ Reaction } & \multicolumn{2}{|c|}{$\mathrm{k} / \mathrm{dm}^{3} \mathrm{~mol}^{-1} \mathrm{~s}^{-1 * 1}$} \\
\hline & & $25^{\circ} \mathrm{C}$ & $250^{\circ} \mathrm{C}$ \\
\hline 1 . & $\mathrm{e}_{\mathrm{aq}^{-}}+\mathrm{e}_{\mathrm{aq}}^{-}+2 \mathrm{H}_{2} \mathrm{O}=\mathrm{H}_{2}+2 \mathrm{OH}^{-}$ & $7.26 \times 10^{9}$ & $5.92 \times 10^{9}$ \\
\hline 2. & $\mathrm{e}_{\mathrm{aq}}^{-}+\mathrm{H}+\mathrm{H}_{2} \mathrm{O}=\mathrm{H}_{2}+\mathrm{OH}^{-}$ & $2.76 \times 10^{10}$ & $4.97 \times 10^{11}$ \\
\hline 3. & $\mathrm{e}_{\mathrm{aq}^{-}}+\mathrm{OH} \quad=\mathrm{OH}^{-}$ & $3.50 \times 10^{10}$ & $3.73 \times 10^{11}$ \\
\hline 4. & $=\mathrm{OH}+\mathrm{OH}^{-}$ & $1.40 \times 10^{10}$ & $3.85 \times 10^{11}$ \\
\hline 5. & $\mathrm{e}_{\mathrm{aq}^{-}}^{-}+\mathrm{O}_{2} \quad=\mathrm{O}_{2}^{-}$ & $2.30 \times 10^{10}$ & $2.18 \times 10^{11}$ \\
\hline 6. & $\mathrm{e}_{\mathrm{aq}}^{-}+\mathrm{O}_{2}^{-}+2 \mathrm{H}_{2} \mathrm{O}=\mathrm{H}_{2} \mathrm{O}_{2}+2 \mathrm{OH}^{-}$ & $1.30 \times 10^{10}$ & $1.61 \times 10^{11}$ \\
\hline 7. & $\mathrm{e}_{\mathrm{aq}}^{-}+\mathrm{HO}_{2} \quad=\mathrm{HO}_{2}^{-}$ & $1.28 \times 10^{10}$ & $1.61 \times 10^{11}$ \\
\hline 8. & $\mathrm{H}+\mathrm{H}=\mathrm{H}_{2}$ & $5.14 \times 10^{9}$ & $1.04 \times 10^{11}$ \\
\hline 9. & $\mathrm{H}+\mathrm{OH}=\mathrm{H}_{2} \mathrm{O}$ & $1.10 \times 10^{10}$ & $6.34 \times 10^{10}$ \\
\hline 10. & $\mathrm{H}+\mathrm{H}_{2} \mathrm{O}_{2}=\mathrm{H}_{2} \mathrm{O}+\mathrm{OH}$ & $3.60 \times 10^{7}$ & $2.15 \times 10^{9}$ \\
\hline 11. & $\mathrm{H}+\mathrm{O}_{2}=\mathrm{HO}_{2}$ & $1.30 \times 10^{10}$ & $6.06 \times 10^{10}$ \\
\hline 12. & $\mathrm{H}+\mathrm{HO}_{2}=\mathrm{H}_{2} \mathrm{O}_{2}$ & $1.13 \times 10^{10}$ & $2.14 \times 10^{11}$ \\
\hline 13. & $\mathrm{H}+\mathrm{O}_{2}^{-}=\mathrm{HO}_{2}^{-}$ & $1.03 \times 10^{10}$ & $2.14 \times 10^{11}$ \\
\hline 14. & $\mathrm{OH}+\mathrm{OH}=\mathrm{H}_{2} \mathrm{O}_{2}$ & $4.80 \times 10^{9}$ & $9.87 \times 10^{9}$ \\
\hline 15. & $\mathrm{OH}+\mathrm{H}_{2}=\mathrm{H}_{2} \mathrm{O}+\mathrm{H}$ & $4.15 \times 10^{7}$ & $7.8 \times 10^{8}$ \\
\hline 16. & $\mathrm{OH}+\mathrm{H}_{2} \mathrm{O}_{2}=\mathrm{HO}_{2}+\mathrm{H}_{2} \mathrm{O}$ & $2.87 \times 10^{7}$ & $4.23 \times 10^{8}$ \\
\hline 17. & $\mathrm{OH}+\mathrm{HO}_{2}=\mathrm{O}_{2}+\mathrm{H}_{2} \mathrm{O}$ & $8.80 \times 10^{9}$ & $3.20 \times 10^{10}$ \\
\hline 18. & $\mathrm{OH}+\mathrm{O}_{2}^{-}=\mathrm{OH}^{-}+\mathrm{O}_{2}$ & $1.10 \times 10^{10}$ & $8.98 \times 10^{10}$ \\
\hline 19. & $\mathrm{HO}_{2}+\mathrm{HO}_{2} \quad=\mathrm{H}_{2} \mathrm{O}_{2}+\mathrm{O}_{2}$ & $8.40 \times 10^{5}$ & $4.10 \times 10^{7}$ \\
\hline 20. & $\mathrm{HO}_{2}+\mathrm{O}_{2}^{-}+\mathrm{H}_{2} \mathrm{O}=\mathrm{H}_{2} \mathrm{O}_{2}+\mathrm{O}_{2}+\mathrm{OH}^{-}$ & $1.00 \times 10^{8}$ & $1.02 \times 10^{7}$ \\
\hline 21. & $\mathrm{O}_{2}^{-}+\mathrm{O}_{2}^{-}+\mathrm{H}_{2} \mathrm{O}=\mathrm{H}_{2} \mathrm{O}_{2}+\mathrm{O}_{2}+\mathrm{OH}^{-}$ & 0.3 & $2.28 \times 10^{4}$ \\
\hline 22. & $\mathrm{H}_{2} \mathrm{O}=\mathrm{H}^{+}+\mathrm{OH}^{-}$ & $2.12 \times 10^{-5}$ & $6.52 \times 10^{-2}$ \\
\hline 23. & $\mathrm{H}^{+}+\mathrm{OH}^{-}=\mathrm{H}_{2} \mathrm{O}$ & $1.18 \times 10^{11}$ & $1.13 \times 10^{12}$ \\
\hline 24. & $\mathrm{H}_{2} \mathrm{O}_{2} \quad=\mathrm{H}^{+}+\mathrm{HO}_{2}^{-}$ & $6.49 \times 10^{-2}$ & $2.52 \times 10^{1}$ \\
\hline 25. & $\mathrm{H}^{+}+\mathrm{HO}_{2}^{-}=\mathrm{H}_{2} \mathrm{O}_{2}$ & $4.52 \times 10^{10}$ & $5.69 \times 10^{11}$ \\
\hline 26. & $\mathrm{H}_{2} \mathrm{O}_{2}+\mathrm{OH}^{-}=\mathrm{HO}_{2}^{-}+\mathrm{H}_{2} \mathrm{O}$ & $1.18 \times 10^{10}$ & $1.36 \times 10^{11}$ \\
\hline 27. & $\mathrm{HO}_{2}^{-}+\mathrm{H}_{2} \mathrm{O}=\mathrm{H}_{2} \mathrm{O}_{2}+\mathrm{OH}^{-}$ & $9.97 \times 10^{5}$ & $1.76 \times 10^{8}$ \\
\hline 28. & $\mathrm{H}=\mathrm{H}^{+}+\mathrm{e}_{\mathrm{aq}}^{-}$ & $3.70 \times 10^{0}$ & $1.65 \times 10^{5}$ \\
\hline 29. & $\mathrm{H}^{+}+\mathrm{e}_{\mathrm{aq}}^{-}=\mathrm{H}$ & $2.02 \times 10^{10}$ & $7.16 \times 10^{11}$ \\
\hline 30. & $\mathrm{e}_{\mathrm{aq}}-+\mathrm{H}_{2} \mathrm{O}=\mathrm{H}+\mathrm{OH}^{-}$ & $1.23 \times 10^{1}$ & $8.03 \times 10^{9}$ \\
\hline 31. & $\mathrm{H}+\mathrm{OH}^{-}=\mathrm{e}_{\mathrm{aq}}^{-}+\mathrm{H}_{2} \mathrm{O}$ & $1.86 \times 10^{7}$ & $2.01 \times 10^{3}$ \\
\hline 32. & $=\mathrm{H}^{+}+\mathrm{O}^{-}$ & $6.49 \times 10^{-2}$ & $2.52 \times 10^{1}$ \\
\hline 33. & $\mathrm{H}^{+}+\mathrm{O}^{-}$ & $4.52 \times 10^{10}$ & $5.69 \times 10^{11}$ \\
\hline 34. & $=\mathrm{O}^{-}+\mathrm{H}_{2} \mathrm{O}$ & $1.33 \times 10^{10}$ & $1.36 \times 10^{11}$ \\
\hline 35. & $=\mathrm{OH}+\mathrm{OH}^{-}$ & $1.27 \times 10^{6}$ & $1.76 \times 10^{8}$ \\
\hline 36. & $=\mathrm{H}^{+}+\mathrm{O}_{2}^{-}$ & $8.19 \times 10^{5}$ & $7.32 \times 10^{8}$ \\
\hline 37. & $\mathrm{H}^{+}+\mathrm{O}_{2}^{-}$ & $5.02 \times 10^{10}$ & $5.69 \times 10^{11}$ \\
\hline 38. & $=\mathrm{O}_{2}^{-}+\mathrm{H}_{2} \mathrm{O}$ & $9.78 \times 10^{-2}$ & $2.87 \times 10^{4}$ \\
\hline 39. & $=\mathrm{HO}_{2}+\mathrm{OH}^{-}$ & $1.18 \times 10^{10}$ & $1.36 \times 10^{11}$ \\
\hline 40. & $=\mathrm{H}+\mathrm{OH}^{-}$ & $1.17 \times 10^{8}$ & $1.55 \times 10^{9}$ \\
\hline 41. & $\mathrm{O}^{-}+\mathrm{H}_{2} \mathrm{O}_{2}=\mathrm{HO}_{2}+\mathrm{OH}^{-}$ & $5.53 \times 10^{8}$ & $8.18 \times 10^{10}$ \\
\hline 42. & $\mathrm{OH}+\mathrm{HO}_{2}^{-}=\mathrm{O}_{2}^{-}+\mathrm{H}_{2} \mathrm{O}$ & $8.29 \times 10^{9}$ & $8.18 \times 10^{10}$ \\
\hline 43. & $\mathrm{O}^{-}+\mathrm{OH}=\mathrm{HO}_{2}^{-}$ & $7.60 \times 10^{9}$ & $3.38 \times 10^{10}$ \\
\hline 44. & $\mathrm{e}_{\mathrm{aq}}^{-}+\mathrm{HO}_{2}^{-}=\mathrm{O}^{-}+\mathrm{OH}^{-}$ & $3.50 \times 10^{9}$ & $6.90 \times 10^{10}$ \\
\hline 45. & $\mathrm{e}_{\mathrm{aq}}^{-}+\mathrm{O}^{-}+\mathrm{H}_{2} \mathrm{O}=\mathrm{OH}^{-}+\mathrm{OH}^{-}$ & $2.31 \times 10^{10}$ & $9.10 \times 10^{10}$ \\
\hline 46. & $\mathrm{O}^{-}+\mathrm{O}_{2}=\mathrm{O}_{3}^{-}$ & $3.47 \times 10^{9}$ & $3.26 \times 10^{10}$ \\
\hline 47. & $\mathrm{O}_{3}^{-}=\mathrm{O}^{-}+\mathrm{O}_{2}$ & $1.90 \times 10^{3}$ & $1.99 \times 10^{7}$ \\
\hline 48. & $\mathrm{H}+\mathrm{H}_{2} \mathrm{O}=\mathrm{OH}+\mathrm{H}_{2}$ & 0 & $2.10 \times 10^{3}$ \\
\hline 49. & $\mathrm{H}_{2} \mathrm{O}_{2} \quad=\mathrm{OH}+\mathrm{OH}$ & 0 & $2.14 \times 10^{-1}$ \\
\hline 50. & $\mathrm{OH}+\mathrm{H}_{3} \mathrm{BO}_{3}=\mathrm{H}_{2} \mathrm{O}+\mathrm{H}_{2} \mathrm{BO}_{3}$ & $5 \times 10^{4}$ & $8.46 \times 10^{5}$ \\
\hline 51. & $\mathrm{e}_{\mathrm{aq}}^{-}+\mathrm{H}_{3} \mathrm{BO}_{3}=\mathrm{H}+\mathrm{H}_{2} \mathrm{BO}_{3}^{-}$ & $3 \times 10^{4}$ & $5.06 \times 10^{5}$ \\
\hline
\end{tabular}

